\title{
Analysis of some Portuguese thermal regulation parameters
}

\author{
Catarina Araújo, Manuela Almeida, Luís Bragança \\ University of Minho, School of Engineering, Department of Civil Engineering, Guimarães, Portugal
}

\begin{abstract}
Due to the high energy consumption associated with the building sector, several legal documents with the aim of promoting energy efficiency have emerged in recent years, e.g. the Directive 2002/91/EC on the energy performance of buildings (EPBD) and its recast on 19 May 2010, Directive 2010/31/EU. The EPBD led many countries to adjust their own building energy-related regulations. The Portuguese thermal regulation for residential buildings, "Regulamento das Características do Comportamento Térmico de Edifícios (RCCTE)", is a part of the transposition of the EPBD to Portuguese law.

The main objective of this paper is to analyse the RCCTE in order to study the influence of some parameters considered important to the energy efficiency of buildings on energy performance and on the final energy certification rating.
\end{abstract}

\section{Introduction}

In the last decades, our planet suffered severe changes that led the world to a serious environmental crisis. Climate change, global warming, the growing emissions of greenhouse gases (GHG) among other related problems have been a growing concern all over the world. The scientific community has discussed the causes of these problems for a long time and nowadays it is a common agreement that some of the main contributors to the increased emissions of the greenhouse gas (GHG) were the production and usage of energy [1-4].

A publication by the Intergovernmental Panel on Climate Change (IPCC) [5] indicates that, in 2007, the largest growth in carbon emissions has come from electricity generation, transportation, industry and, above all, from building operation.

Energy-related GHG emissions currently accounts for $77 \%$ of total emissions in the EU-27 [6]. Nevertheless, the problems related to energy are not strictly environmental. One of the biggest concerns of many countries is their high dependency on imported energy [7]. Figure 1 presents the relation between the consumption, importation and production of energy in the European Union. According to the Energy and Environment Report 2008 from the European Environment Agency (EEA) [8] and to the Green Paper towards a European Strategy for the Security of Energy Supply 2000 [9], 54\% of Europe's primary energy is imported and this dependency is expected to rise to $70 \%$ by 2030 .

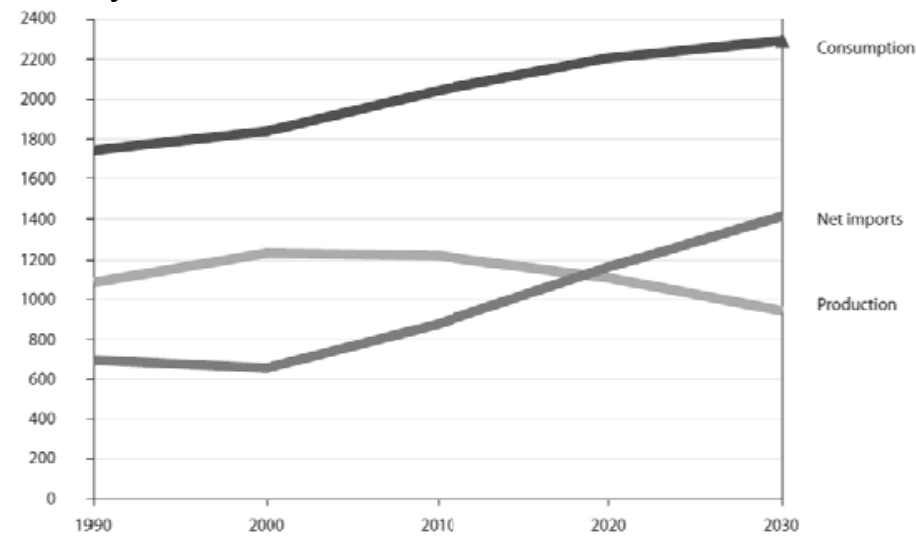

Figure 1 - Relation between energy consumption, importation and production in the EU [9]. 
The building sector is also an important contributor to the environmental problems. It is responsible for the depletion of two-fifths of global raw stone, gravel and sand and one-fourth of virgin wood, three billion tons of raw materials, turned into foundations, walls, pipes, and panels and $16 \%$ of water. It is responsible for consuming approximately $40 \%$ of the final energy in Europe and for nearly $50 \%$ of greenhouse gas emissions [10-12].

The European Union cannot easily change its supply condition and therefore it is important to intervene on the energy demand [9], [13] since 20\% of Europe's energy consumption can be reduced trough energy efficiency measures [14].

According to the Energy Efficiency Plan 2011, the greatest energy saving potential lies in buildings [13]. In fact, despite the high environmental impact related to buildings, this sector also presents great potential of reduction in GHG emissions through the application of cost-effective technical and non-technical measures to existing building stock and new construction [15].

In Portugal, the building sector is responsible for the consumption of approximately $30 \%$ of the final energy, but $50 \%$ of this consumption can be reduced through energy efficiency measures. This can represent an annual reduction of 400 million tons of $\mathrm{CO}_{2}[16]$.

\section{European energy efficiency policies}

Parameshwaran et al. [17] have pointed out that the energy challenges can be effectively tackled by two means: the development of energy efficiency techniques and the implementation of strategic policies and measures for addressing the growing energy security and environmental concerns.

Due to these concerns, in the last decade, a significant number of directives and laws related to energy efficiency have emerged in the European Union [18]. Some of these directives are: Directive 2006/32/EC on the energy end-use efficiency and energy services [19]; Directive 2005/32/EC establishing a framework for the setting of ecodesign requirements for energy-using products (EuP) [20]; Directive 2004/8/EC on the promotion of cogeneration based on a useful heat demand in the internal energy market [21]; Directive 2003/30/EC on the promotion of the use of biofuels or other renewable fuels for transport [22]; and Directive 2002/91/EC on the energy performance of buildings (EPBD) [23].

The objective of the EPBD is to promote the improvement of the energy performance of buildings within the Community, taking into account outdoor climatic and local conditions, as well as indoor climate requirements and cost-effectiveness. This Directive imposes the following requirements to Member States: the application of a methodology for assessing the energy performance of buildings; minimum requirements on the energy performance of new buildings and large existing buildings subject to major renovations; the issuance of an energy performance certificate when buildings are constructed, sold, or rented out; and regular inspections of boilers and air conditioning systems in buildings [23].

The EPBD specifically tackles energy dependency via actions aimed at reducing consumption and therefore has a direct effect on energy demand [24]. Mlecnik et al. [25] stated that, with some adjustments and with greater involvement of companies, the Directive has the potential to increase energy efficiency.

However, some Member States had low ambitions upon defining their regulations and some did not even complete the process of transposing the Directive to national law [24]. Thus, on the 19th of May 2010, the Member States signed a recast to the 2002 EPBD, i.e., the Directive 2010/31/EU. The challenge of this new document is to achieve a higher level of energy building performance, even nearly zero energy, at a cost-optimal level [12].

The 2010 EPBD recast brought considerable progress to attain the EU energy efficiency objectives, since it requires that beyond 2018 all public buildings should be near zero energy buildings (NZEB), and in 2020 the same target should be achieved for all other new buildings and major refurbishments [26]. 


\section{EPBD and the Portuguese building thermal legislation}

The first piece of Portuguese legislation regarding the energy performance of buildings was Decree Law 40/90 of 1990 [27]. This regulation set the first Portuguese requirements related to the implementation of energy efficiency measures in buildings. It also limited the heating and the cooling energy needs, as well as the heat transfer coefficient (U) of the envelope walls and the Solar Heating Gain Coefficient of the glazing solutions. However, the requirements of this regulation were not very demanding. During two decades, the thermal comfort of buildings and their energy efficiency were a matter of low importance to the Portuguese design teams.

In 2006 this reality has changed with the transposition of the 2002 EPBD to the Portuguese legislation. This transposition has been performed through the following three legal documents:

- Decree 78/2006, which creates and defines the operational rules for the System for Energy and Indoor Air quality Certification of Buildings (SCE) [28];

- Decree 79/2006, which sets the thermal regulation for service buildings (Regulation of Air Conditioning Energy Systems in Buildings - RSECE) [29];

- Decree 80/2006, which sets the thermal regulation for residential buildings (Regulation of the Characteristics of the Thermal Behaviour of Buildings - RCCTE) [30].

The RCCTE is the main focus of this study. It increases the minimal thermal requirements of buildings, promotes the use of renewable energy and supports the use of certified materials [31].

The RCCTE's calculation method allows us to determine the energy performance of buildings and to assign a grade in a scale from $\mathrm{A}+$ to $\mathrm{G}$ (Figure 2). This grade is obtained by an index (R), which results from the ratio between the calculated annual primary energy needs $(\mathrm{Ntc})$ and the maximum annual primary energy needs $(\mathrm{Nt})$.
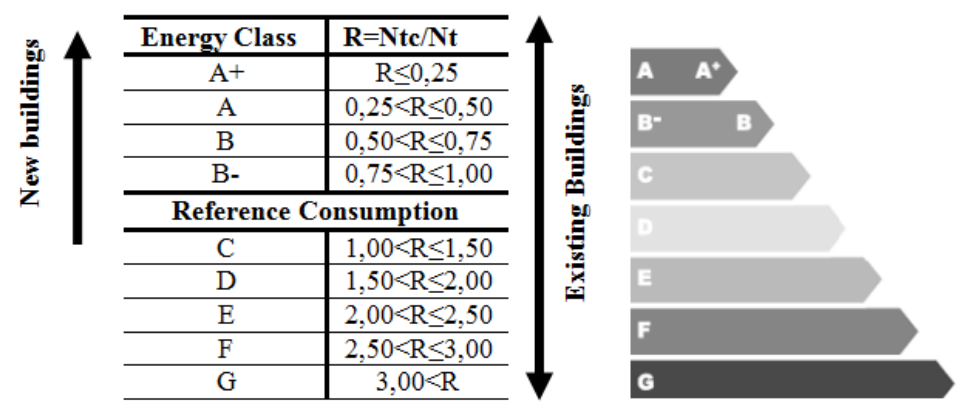

Figure 2. Portuguese building energy certification scheme. Adapted from [32]

According to the energy classification adopted by the SCE, the most efficient building (class $\mathrm{A}+$ ) may consume less than $1 / 4$ of the energy consumed by a "reference building", while the least efficient (class G) can consume over 300\% more than that [27].

The RCCTE imposes the following requirements to all new buildings and to existing buildings subject to major renovations:

- Maximum heat transfer coefficients (U) for current envelope elements;

- Maximum solar factor for windows not facing north and with an area greater than $5 \%$ of the serving room;

- The installation of solar systems;

- The issuance of an energy certificate with an energy class of, at least, B-.

As for existing buildings, the RCCTE requires that they have an energy certificate only when subject to sale or rental operations.

When compared to Decree 40/90, the RCCTE 2006 has much more demanding requirements. Due to this change, the building sector stakeholders were confronted with the need to adjust the way of dimensioning the several elements that interfere with the new legal document. The regulation has become more complex and its requirements much more restrictive. 
Thus, it is important to perform an analysis on the present regulation in order to identify, in a much clearer way, the main parameters that interfere with the calculation of the energy indexes and with the building energy rating.

Several other studies have already been performed regarding the Portuguese thermal regulation and the implementation of the EPBD in some European countries.

As far as the Portuguese thermal regulation is concerned, Ferreira and Domingos [27] have conducted an analysis in order to determine if the Portuguese thermal regulations are consistent in terms of energy efficiency and environmental performance. Ferreira and Pinheiro [26] have also analysed the Portuguese energy certification system and regulation applied to the residential sector. The authors have further examined the importance of bioclimatic measures in the Portuguese implementation of the EPBD through comparison with the Passivehaus Norm applied to warm countries in Europe.

Additionally, Panão et al. [43] have studied the performance of the RCCTE calculations related to cooling energy needs when compared with the results obtained by dynamic simulation tools.

Concerning the EPBD, several studies have looked into its implementation in the European countries, e.g. the study performed by Dascalacki et al [44] in Greece, by Tronchin and Fabbri [45] in Italy or by Paul and Lees [46] in the UK. However, these studies have focused on the implementation of the EPBD, the precision of the derived national regulations or the impact of the Directive on the buildings' energy use.

Andaloro et al [24] have examined the implementation of the EPBD in the 27 EU Member States. The implementation was analysed on the basis of two parameters: uniformity and excellence. Uniformity assesses the degree of harmony of the individual Member States with regard to the parameters laid down by the European Commission, and excellence allows for the Member States to be appraised and the "best" performers to be identified.

Besides the importance of these studies to the state of the art, the work presented in this paper is innovative as it intends to study some RCCTE parameters that influence the energy efficiency of buildings, calculating their relative importance. The study develops a methodology through parametric analysis that can be applied to present-day regulations as well as future energetic regulations that will result from the transposition of the requirements of the new 2010 EPBD to the Portuguese legislation. Thus, it will be possible to understand the benefits in terms of energy efficiency and rating that result from changing certain parameters, thereby allowing for the comparison of different alternatives.

\section{Methodology}

For residential buildings, some parameters were chosen and a parametric analysis was carried out based on a case study building in order to assess their influence on the building's thermal performance.

The analysed parameters were the following:

i) the heat transfer coefficient $(U)$ of walls and slabs belonging to the exterior and interior envelope, thermal bridges and windows;

ii) the number of indoor air changes per hour (Rph);

iii) the solar factor $(\mathrm{g})$ of the windows;

iv) the shading factor (Fs) of vertical and horizontal windows;

v) the absorption factor $(\alpha)$ of the external walls;

vi) the efficiency of Domestic Hot Water (DHW) preparation systems ( $\eta$ a);

vii) the contribution of solar systems to DHW preparation (Esolar);

viii) the heating system efficiency ( $\eta \mathrm{i})$; and

ix) the cooling system efficiency ( $\eta v)$. 
For each of the abovementioned parameters, alternative solutions to the conventional reference solutions were investigated. The selected alternative solutions include at least one high-performance solution, one low-performance solution and two other different solutions. In any case, all the selected solutions are used and marketed in Portugal. The reference solutions of the case study were chosen in order to be representative of a large number of solutions commonly used for detached single-family houses in Portugal.

After selecting all the solutions to be simulated, the energy calculations were performed according to the methodology of the Portuguese residential buildings regulation. Through the variation of each energy index caused by the change in each parameter, the influence of each parameter on the final building energy rating was discussed.

The influence of each parameter on the building's final energy label will be demonstrated and discussed below.

\section{Case Study}

The case study selected to perform the parametric analysis is a detached single-family house located in the North of Portugal.

Figure 3 presents the building distribution according to geographic zones in Portugal. Portugal has around 3.500.000 buildings and around 5.700.000 dwellings and the North is the geographic zone with the largest number of buildings (around 1.200.000 buildings and 1.800 .000 dwellings). Detached houses are one of the most common types of constructions in Portugal and the vast majority of buildings $(90.7 \%)$ were structurally built to have 1 or 2 dwellings (INE 2011).

Building distribution

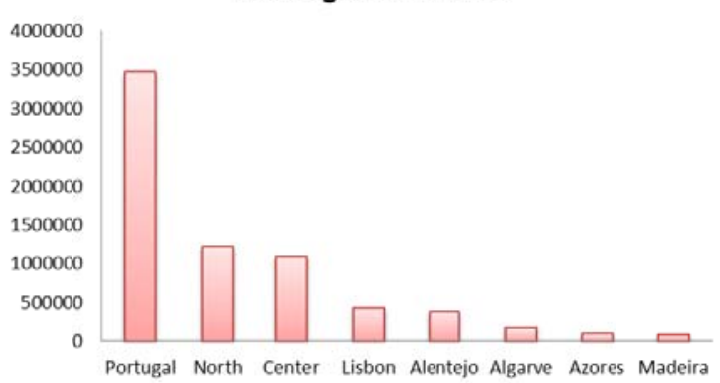

Dwelling distribution

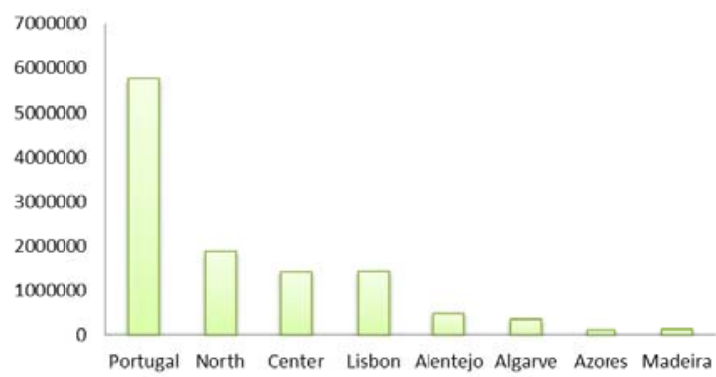

Figure 3. Building and dwelling distribution according to geographic zones in Portugal.

The selected case study is indeed representative of a significant number of buildings in Portugal. This case study concerns a four-room detached single-family house with a heated area of $271.57 \mathrm{~m}^{2}$. It is located in Ponte de Lima (Northwest of Portugal) at an altitude of $74 \mathrm{~m}$ and about $25 \mathrm{~km}$ away from the Atlantic Ocean coast. According to the Portuguese legislation, the climatic region of this building is I2, V2 North (between the most severe, I3 V3, and the mildest, I1 V1, climatic regions) and its thermal inertia is classified as strong (above $400 \mathrm{~kg} / \mathrm{m}^{2}$ ).

The case study building, which will be referred to as the reference solution, observes all the legislative thermal requirements and its energy label is B- (low thermal quality since B- is the minimum label allowed for new buildings).

\section{Results}

The detailed analysis performed on the heat transfer coefficient of the exterior walls will be explained as an example. The results obtained for the other studied parameters will only be presented and discussed. 


\subsection{Heat transfer coefficient}

To achieve energy efficiency in buildings, it is very important to reduce the heat transfer through the building's envelope [33], which is why the heat transfer coefficient is one of the parameters analysed within the present study.

The heat transfer coefficient of an element is defined as the heat quantity per time unit that crosses a surface of one unit area per unit of temperature difference between the environments separated by the element [30].

As stated above, the RCCTE imposes a maximum value on the heat transfer coefficients of current envelope elements.

\subsubsection{Walls belonging to the exterior envelope}

The solutions presented in Table 1 were used to carry out the analysis of the influence exerted by the heat transfer coefficient of walls belonging to the exterior envelope. Two types of construction solutions were studied: double walls and External Thermal Insulation Composite Systems (ETICS). These two construction systems were chosen because they are the most widely used solutions in Portugal nowadays.

Table 1 . Solutions under study to analyse the influence of the exterior walls heat transfer coefficient.

\begin{tabular}{|l|l|}
\hline \multicolumn{1}{|c|}{ Solution } & $\mathrm{U}\left(\mathrm{W} / \mathrm{m}^{2} \cdot{ }^{\circ} \mathrm{C}\right)$ \\
\hline $\begin{array}{l}1-\text { Reference Solution: Double masonry wall } 15+11(\mathrm{~cm}) \\
\text { with 4cm of extruded polystyrene }(X P S)\end{array}$ & 0.50 \\
\hline 1.1 - Double masonry wall $15+11(\mathrm{~cm})$ with $3 \mathrm{~cm}$ of XPS & 0.58 \\
\hline 1.2 - Double masonry wall $15+11(\mathrm{~cm})$ with $8 \mathrm{~cm}$ of XPS & 0.32 \\
\hline 1.3 - Double masonry wall $22+22(\mathrm{~cm})$ with $8 \mathrm{~cm}$ of XPS & 0.28 \\
\hline 1.4 - ETICS $(15 \mathrm{~cm})$ with $4 \mathrm{~cm} \mathrm{XPS}$ & 0.58 \\
\hline 1.5 - ETICS $(15 \mathrm{~cm})$ with $8 \mathrm{~cm} \mathrm{XPS}$ & 0.35 \\
\hline 1.6 - ETICS $(22 \mathrm{~cm})$ with $8 \mathrm{~cm}$ XPS & 0.33 \\
\hline
\end{tabular}

The results obtained for the different exterior wall solutions are presented in Figure 4. In this figure, the dark grey bar represents the maximum regulatory values for heating needs $(\mathrm{Ni})$, cooling needs $(\mathrm{Nv})$ and primary energy needs $(\mathrm{Nt})$. The light grey bars represent the heating needs (Nic), cooling needs $(\mathrm{Nvc})$ and primary energy needs $(\mathrm{Ntc})$ of each solution.

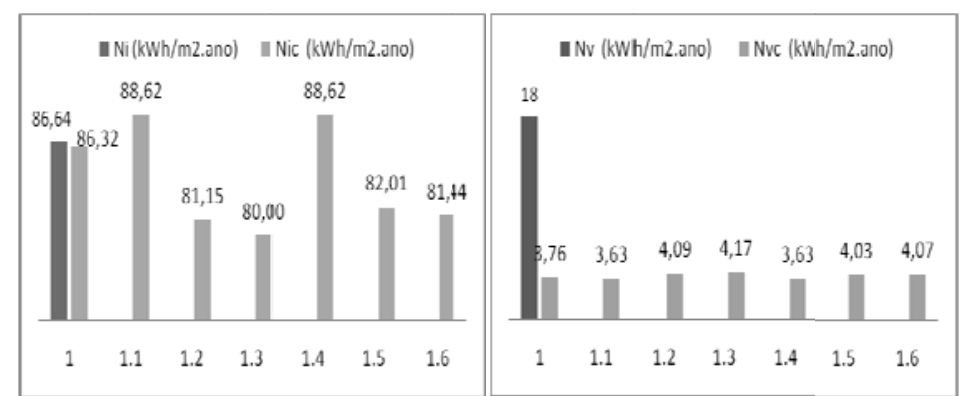

b)

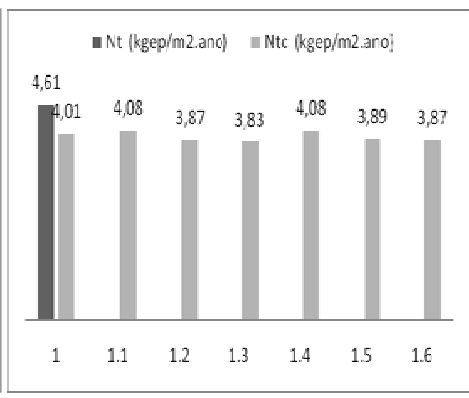

c)

Figure 4. Results obtained for the analysed exterior wall solutions. a) Building's heating needs (Nic). b) Building's cooling needs (Nvc). c) Annual primary energy needs (Ntc).

Through the overall results obtained, it was possible to verify that the solutions that have better performance in the heating season are those which have the worst performance in the cooling season.

It was also verified that, with an increase in the insulation thickness, the influence on the element's $U$ value decreases. At a certain point, the increase in the insulation thickness has very 
limited influence on the element's $U$ value and on the corresponding contribution to the overall heating needs (Nic value).

For the two types of construction solutions studied (double masonry walls and ETICS), it was observed that both have similar performances although the double masonry walls have a slightly better performance. The ETICS system can, however, be considered a viable alternative system to the double walls regarding the building's thermal behaviour.

All solutions comply with the minimum requirements of the RCCTE for the climate zone of the reference solution. It was verified that a simple $15 \mathrm{~cm}$ thick masonry wall without any insulation fulfils the requirements. Thus, the minimum requirements for the exterior walls for the I2 V2 climate zone are not very demanding.

Table 2 presents the results obtained for the solutions with high and low heat transfer coefficients and the differences between both.

Table 2. Differences between solutions with high and low heat transfer coefficients (analysis of external walls)

\begin{tabular}{|l|c|c|c|c|}
\cline { 2 - 5 } \multicolumn{1}{c|}{} & Nic & $\mathrm{Nvc}$ & Nac & Ntc \\
\cline { 2 - 5 } \multicolumn{1}{c|}{} & \multicolumn{3}{c|}{$\left(\mathrm{kWh} / \mathrm{m}^{2} \cdot\right.$ year $)$} & $\left(\mathrm{kgep} / \mathrm{m}^{2} \cdot\right.$ year) \\
\hline Umin $=0.28 \mathrm{~W} / \mathrm{m}^{20} \mathrm{C}$ (Solution 1.3$)$ & 80.00 & 4.17 & 17.12 & 3.83 \\
\hline Umax $=0.58 \mathrm{~W} / \mathrm{m}^{20} \mathrm{C}$ (Solution 1.1$)$ & 88.62 & 3.63 & 17.12 & 4.08 \\
\hline Variation of energy needs & 8.62 & 0.73 & 0.00 & 0.25 \\
\hline
\end{tabular}

The Nac index represents the DHW energy needs of the building. However, this index is not influenced by this parameter.

It can be observed that the heat transfer coefficient of the exterior walls has a relevant influence on the Nic value. The solutions with the highest and the lowest $U$ values lead to a significant variation of the Nic value.

It was further verified that the influence of these parameters regarding summer comfort conditions is not negligible. The final energy label of the building is derived from an index which is directly proportional to primary energy needs. Thus, as this parameter has a small influence in terms of primary energy needs, it has also a small influence on the final rating of the building.

\subsubsection{Walls belonging to the interior envelope}

The walls belonging to the interior envelope (i.e., walls in contact with non-heated spaces) do not have, in the reference solution, any influence regarding the energy indexes, since they are all in contact with a non-heated space that, in this case, is at the same temperature as the building $\left(20^{\circ} \mathrm{C}\right)$. Therefore no heat losses are to be considered through them. However, any modification on their constitution will have an impact on the thermal inertia of the building. Because of this, four solutions were studied, which correspond to different thicknesses of the brick used. Nevertheless, it was verified that the thermal inertia class did not change and hence these elements bear no influence on the final energy label of the building under study.

\subsubsection{Slabs}

The influence of the heat transfer coefficient of the slabs was studied by taking into consideration the existing construction solution of the reference building. Four solutions were considered: three with different insulation thicknesses and one where the position of the insulation was changed.

The results obtained with the different heat transfer coefficients considered are presented in Table 3 . This table shows three different situations: two correspond to floor slabs with different types of coating $\left(\mathrm{U}_{(\mathrm{LII})}\right.$ e $\left.\mathrm{U}_{(\mathrm{LI} 2)}\right)$ and one corresponds to a ceiling slab $\left(\mathrm{U}_{(\mathrm{LS})}\right)$. 
Table 3. Differences between solutions with high and low heat transfer coefficients (analysis of slabs)

\begin{tabular}{|c|c|c|c|c|}
\hline & Nic & Nvc & $\mathrm{Nac}$ & \multirow{2}{*}{$\frac{\mathrm{Ntc}}{\left(\mathrm{kgep} / \mathrm{m}^{2} \cdot \text { year }\right)}$} \\
\hline & \multicolumn{3}{|c|}{$\left(\mathrm{kWh} / \mathrm{m}^{2} \cdot\right.$ year $)$} & \\
\hline $\begin{array}{l}\mathrm{U}_{(\mathrm{LI} 1 \mathrm{~min})}=0.20 ; \mathrm{U}_{(\mathrm{LI} 2 \mathrm{~min})}=0.32 \text { e } \mathrm{U}_{(\mathrm{LSmin})}=0.34 \\
(\mathrm{Slab} \text { with } 8 \mathrm{~cm} \text { of XPS) }\end{array}$ & 76.37 & 3.76 & 17.12 & 3.72 \\
\hline $\begin{array}{l}\mathrm{U}_{(\mathrm{LI} 1 \mathrm{max})}=0.60 ; \mathrm{U}_{(\mathrm{LI2max})}=0.58 ; \mathrm{U}_{(\mathrm{LSmax})}=0.67 \\
(\text { Slab with } 3 \mathrm{~cm} \text { of XPS) }\end{array}$ & 92.25 & 3.76 & 17.12 & 4.18 \\
\hline Variation of energy needs & 15.88 & 0.00 & 0.00 & 0.46 \\
\hline
\end{tabular}

The results presented in Table 3 illustrate the significant influence of this parameter on heating demands and comfort conditions during the heating season.

However, these results may not be so expressive in other building types because they are related to the large contact area of the ceiling slab with a non-heated space, which leads to substantial heat losses.

\subsubsection{Thermal bridges}

A thermal bridge is a building element where a significant change in the thermal resistance, compared to that of the envelope, occurs due to the presence of materials with a higher thermal conductivity and due to the change in the geometry of the fabric, as in the case of the junction between roofs, floors, ceilings and walls [34].

Heat losses through thermal bridges increase winter heat losses and summer heat gains [35] and lead to building pathologies generated by moisture [36]. Thus, they are an important factor for building energy efficiency and thermal comfort.

The heat transfer coefficient of the thermal bridges was analysed by considering different thermal insulation thicknesses. Table 4 shows the results obtained for the solutions studied.

Table 4. Differences between solutions with high and low heat transfer coefficients (analysis of thermal bridges)

\begin{tabular}{|l|c|c|c|c|c|}
\cline { 2 - 5 } \multicolumn{1}{c|}{} & Nic & Nvc & Nac & Ntc \\
\cline { 2 - 5 } \multicolumn{1}{c|}{} & \multicolumn{2}{c|}{$\left(\mathrm{kWh} / \mathrm{m}^{2} \cdot\right.$ year $)$} & $\left(\mathrm{kgep} / \mathrm{m}^{2} \cdot\right.$ year $)$ \\
\hline $\begin{array}{l}\text { Umin }=0.32 \mathrm{~W} / \mathrm{m}^{20} \mathrm{C} \\
(\text { Plane thermal bridges with 8cm of XPS })\end{array}$ & 86.16 & 3.77 & 17.12 & 4.01 \\
\hline $\begin{array}{l}\text { Umax }=2.00 \mathrm{~W} / \mathrm{m}^{2 \circ} \mathrm{C} \\
\text { (Plane thermal bridges without insulation })\end{array}$ & 86.86 & 3.73 & 17.12 & 4.03 \\
\hline Variation of energy needs & 0.70 & 0.04 & 0.00 & 0.02 \\
\hline
\end{tabular}

The values shown in the table indicate that the building energy needs are not significantly influenced by the heat transfer coefficients of the thermal bridges. This is because, in the reference solution, the thermal bridge area is small. Therefore, if other buildings have larger thermal bridge areas, these elements might bear a greater influence.

In fact, the treatment of these elements is a matter of extreme importance, and several studies [35] [37] have stated that they are highly influential concerning building thermal comfort.

\subsubsection{Glazing}

In this case different types of glass and window frames were analysed by taking into account some window solutions described in the official publication ITE50 [38]. The results obtained for the different analysed solutions are presented in Table 5 .

The building comfort conditions in both heating and cooling seasons are influenced by this parameter, as shown in Table 5. 
Table 5. Differences between solutions with high and low heat transfer coefficients (glazing)

\begin{tabular}{|l|c|c|c|c|c|}
\cline { 2 - 5 } \multicolumn{1}{c|}{} & Nic & Nvc & Nac & Ntc \\
\cline { 2 - 5 } \multicolumn{1}{c|}{$\begin{array}{l}\text { Umin }=2 \mathrm{~W} / \mathrm{m}^{2 \mathrm{o}} \mathrm{C} \text { (Double glass, plastic window frames } \\
\text { without thermal break) }\end{array}$} & 81.91 & 4.32 & 17.12 & 3.89 \\
\hline $\begin{array}{l}\text { Umax }=4.1 \mathrm{~W} / \mathrm{m}^{2 \circ} \mathrm{C} \text { (Simple glass, metal window frames } \\
\text { without thermal break) }\end{array}$ & 90.33 & 3.31 & 17.12 & 4.12 \\
\hline Variation of energy needs & 8.42 & 1.01 & 0.00 & 0.23 \\
\hline
\end{tabular}

With respect to energy efficiency, windows are an important element in buildings because they can contribute substantially to the reduction of the heating and cooling demands [39]. As observed in Table 5, the calculations of the RCCTE reflect this importance since this parameter has a substantial influence both on building heating and cooling needs.

\subsection{Number of indoor air changes per hour}

The ventilation of a building is an important factor to provide adequate indoor air quality, as well as to achieve energy efficiency. Misjudging the air infiltration can lead to an under or over dimensioned ventilation system and to an inadequate demand of energy [40].

The study of the influence of the indoor air change rate (Rph) was performed by taking into consideration the existence, or not, of three items: window frames labelled by EN12207, air admission devices on the façade and mechanical ventilation.

Table 6. Differences between solutions with high and low number of indoor air changes per hour

\begin{tabular}{|c|c|c|c|c|}
\hline & Nic & Nvc & $\mathrm{Nac}$ & \multirow{2}{*}{$\frac{\mathrm{Ntc}}{\left(\mathrm{kgep} / \mathrm{m}^{2} \cdot \text { year}\right)}$} \\
\hline & \multicolumn{3}{|c|}{$\left(\mathrm{kWh} / \mathrm{m}^{2} \cdot\right.$ year $)$} & \\
\hline Rph $\min =0.66$ (mechanical ventilation) & 74.35 & 6.52 & 17.12 & 3.69 \\
\hline $\begin{array}{l}\text { Rph max }=0.95 \text { (Window frame without classification } \\
\text { and without air admission devices on the façade) }\end{array}$ & 86.32 & 3.76 & 17.12 & 4.01 \\
\hline Variation of energy needs & 11.97 & 2.76 & 0.00 & 0.32 \\
\hline
\end{tabular}

Table 6 shows the significant influence this parameter has during heating and cooling seasons. However, as regards energy labelling this influence is not so significant.

\subsection{Solar factor of the windows}

The solar factor of the windows is the ratio between the solar energy transmitted through the glass and the solar energy incident upon it [30].

The thermal regulation calculations include different solar factors both for cooling and heating seasons. The study for the summer solar factor consisted in the analysis of different kinds of glass and external solar protections. The winter solar factor was studied through the analysis of different types of internal solar protections.

\subsubsection{Summer Solar Factor $\left(g_{\text {Summer }}\right)$}

The summer solar factor is dependent on the type of glass (30\%) and on the type of external solar protection (70\%). Table 7 presents the results obtained in the analysis of the glass type, and Table 8 presents the results of the analysis of the external solar protection type. 
Table 7. Differences between solutions with high and low solar factor (glass type analysis)

\begin{tabular}{|c|c|c|c|c|}
\hline & Nic & Nvc & $\mathrm{Nac}$ & \multirow{2}{*}{$\begin{array}{c}\text { Ntc } \\
\left(\mathrm{kgep} / \mathrm{m}^{2} \cdot \text { year }\right)\end{array}$} \\
\hline & \multicolumn{3}{|c|}{$\left(\mathrm{kWh} / \mathrm{m}^{2} \cdot\right.$ year $)$} & \\
\hline $\begin{array}{l}\mathrm{g}_{\text {Summer }} \min =0.43(\text { Double glass }- \text { reflective, coloured in } \\
\text { mass }+ \text { clear glass }(4 \mathrm{~mm}+8 \mathrm{~mm})\end{array}$ & 86.32 & 2.69 & 17.12 & 4.00 \\
\hline $\mathrm{g}_{\text {Summer }} \max =0.59($ Simple Glass - clear glass $4 \mathrm{~mm})$ & 89.53 & 4.16 & 17.12 & 4.11 \\
\hline Variation of energy needs & 3.21 & 1.47 & 0.00 & 0.11 \\
\hline
\end{tabular}

Table 8. Differences between solutions with high and low solar factor (external protection analysis)

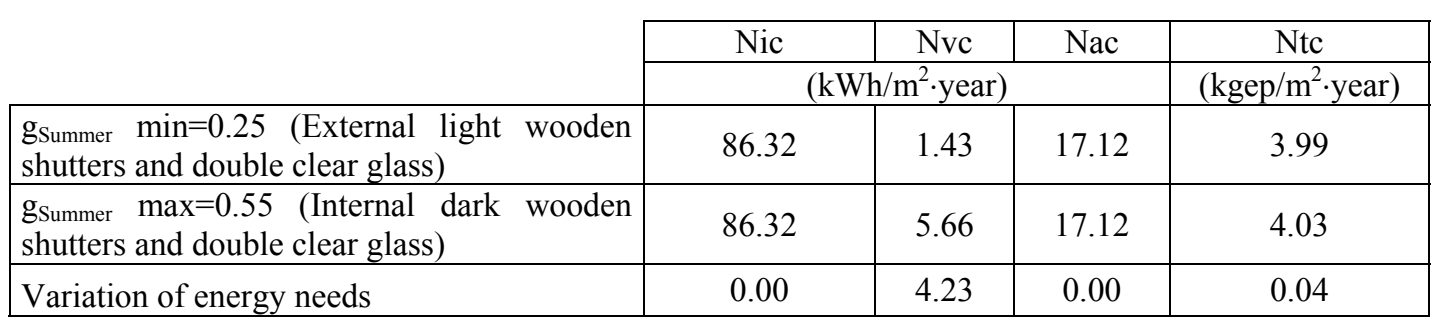

The variation of glass type has significantly influenced the cooling needs. As in previous studies, Ntc variation is low, meaning that the influence of glass type on this index is small.

The influence of external solar protection on the Nvc value is even greater than the influence of glass type. However, with regard to primary energy needs and to building energy label this influence is reduced.

\subsubsection{Winter solar factor $\left(g_{\text {Winter }}\right)$}

As shown in Table 9, the interior solar protection has little influence over the comfort conditions during the heating season. However, as in many previous parameters, the Ntc index is slightly influenced by these elements.

Table 9. Differences between solutions with high and low winter solar factor

\begin{tabular}{|c|c|c|c|c|}
\hline \multirow{2}{*}{ (2) } & Nic & $\mathrm{Nvc}$ & $\mathrm{Nac}$ & \multirow{2}{*}{$\frac{\mathrm{Ntc}}{\left(\mathrm{kgep} / \mathrm{m}^{2} \cdot \text { year }\right)}$} \\
\hline & \multicolumn{3}{|c|}{$\left(\mathrm{kWh} / \mathrm{m}^{2} \cdot\right.$ year $)$} & \\
\hline $\begin{array}{l}\mathrm{g}_{\text {Winter }} \min =0.30 \text { (Light wooden shutters (opaque) with } \\
\text { simple clear glass) }\end{array}$ & 91.67 & 3.76 & 17.12 & 4.17 \\
\hline $\begin{array}{l}g_{\text {Winter }} \text { max }=0.70 \text { (Very transparent light curtains and } \\
\text { simple clear glass) }\end{array}$ & 85.19 & 3.76 & 17.12 & 4.01 \\
\hline Variation of energy needs & 6.48 & 0.00 & 0.00 & 0.16 \\
\hline
\end{tabular}

\subsection{Shading factor}

The shading factor represents the reduction of solar radiation on windows due to permanent shading caused by various obstacles [30].

The study of the influence of the shading factor was carried out by evaluating the effects of horizontal and vertical shading elements. To do so, several shading elements with different sizes were evaluated in the main building's orientations.

\subsubsection{Horizontal Shading (Fo)}

As far as horizontal shading is concerned, Table 10 shows that these devices have an influence on both Nic and Nvc indexes. However, this influence is greater in terms of cooling needs. It was verified that the shading solutions that decrease the heating needs also increase the cooling needs. For this reason, this parameter is not highly influential on the primary energy needs. 
Table 10. Differences between solutions with high and low $\alpha$ value (horizontal shading analysis)

\begin{tabular}{|l|c|c|c|c|}
\multicolumn{1}{c|}{} & Nic & Nvc & Nac & Ntc \\
\cline { 2 - 5 } \multicolumn{1}{c|}{} & \multicolumn{3}{c|}{$\left(\mathrm{kWh} / \mathrm{m}^{2} \cdot\right.$ year $)$} & $\left(\mathrm{kgep} / \mathrm{m}^{2} \cdot\right.$ year $)$ \\
\hline Fo min (Without shading $\left.\alpha=0^{\circ}\right)$ & 85.72 & 4.32 & 17.12 & 4.00 \\
\hline Fo max (All windows shaded with $\left.\alpha=60^{\circ}\right)$ & 89.32 & 2.07 & 17.12 & 4.08 \\
\hline Variation of energy needs & 3.60 & 2.25 & 0.00 & 0.08 \\
\hline
\end{tabular}

Note: $\alpha$ is the angle between the plane of the glass and the line joining the midpoint of the glass to the edge of the horizontal shading device.

\subsubsection{Vertical shading (Ff)}

The vertical shading devices have little influence on both cooling and heating needs. When it comes to cooling needs, horizontal shading devices have a higher influence than vertical shading devices (Table 10 and Table 11).

Table 11. Differences between solutions with high and low $\alpha$ value (vertical shading analysis)

\begin{tabular}{|l|c|c|c|c|}
\cline { 2 - 4 } \multicolumn{1}{c|}{} & Nic & Nvc & Nac & Ntc \\
\cline { 2 - 5 } \multicolumn{1}{c|}{} & \multicolumn{3}{c|}{$\left(\mathrm{kWh} / \mathrm{m}^{2} \cdot\right.$ year $)$} & $\left(\mathrm{kgep} / \mathrm{m}^{2} \cdot\right.$ year $)$ \\
\hline Ff min (Without shading, $\left.\beta=0^{\circ}\right)$ & 85.15 & 3.78 & 17.12 & 4.01 \\
\hline Ff max (All vain shadows with $\left.\beta=60^{\circ}\right)$ & 88.47 & 3.30 & 17.12 & 4.07 \\
\hline Variation of energy needs & 2.32 & 0.48 & 0.00 & 0.06 \\
\hline
\end{tabular}

Note: $\beta$ is the angle between the plane of the glass and the line joining the midpoint of the glass to the edge of the vertical shading device.

\subsection{Absorption coefficient ( $\alpha$ ) of the external walls}

The absorption coefficient is dependent on the colour of the exterior walls. The influence of this parameter was evaluated through the analysis of three kinds of paint colours - light, medium and dark - as described in the regulation [30].

Table 12. Differences between solutions with high and low $\alpha$ value

\begin{tabular}{|l|c|c|c|c|}
\cline { 2 - 5 } \multicolumn{1}{c|}{} & Nic & Nvc & Nac & Ntc \\
\cline { 2 - 5 } \multicolumn{1}{c|}{} & \multicolumn{3}{c|}{$\left(\mathrm{kWh} / \mathrm{m}^{2} \cdot\right.$ year $)$} & $\left(\mathrm{kgep} / \mathrm{m}^{2} \cdot\right.$ year $)$ \\
\hline$\alpha \min =0.4$ (External walls with light colour finishing) & 86.39 & 3.76 & 17.12 & 4.01 \\
\hline$\alpha \max =0.8$ (External walls with dark colour finishing) & 86.39 & 5.05 & 17.12 & 4.02 \\
\hline Variation of energy needs & 0.00 & 1.29 & 0.00 & 0.01 \\
\hline
\end{tabular}

The comfort conditions in the cooling season are considerably influenced by this parameter, as shown in Table 12. Moreover, the Ntc index is once again slightly influenced by the variation of a single parameter.

\subsection{Efficiency of DHW preparation systems}

Several types of equipment with different efficiencies and fed by different fuels were studied in order to evaluate the influence of the efficiency of DHW preparation systems ( $\eta \mathrm{a})$.

The study demonstrated that the equipment with the worst efficiency is the one that leads to the highest Nac index; it is not the one that leads to the highest primary energy needs. This fact is the reason why the results of the parametric study performed for this parameter are presented in two tables instead of one.

Through the results recorded in Table 13 and Table 14, the large influence of this parameter becomes clear from both the Nac index and the primary energy needs. 
Table 13. Differences between solutions with high and low ๆa

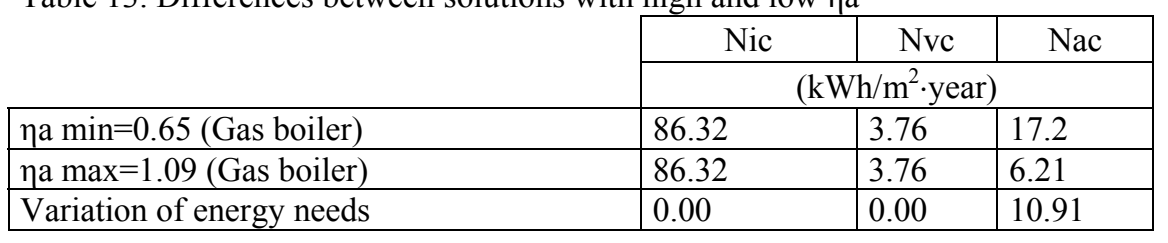

Table 14. Differences between solutions that lead to a high and low Ntc

\begin{tabular}{|l|l|}
\cline { 2 - 2 } \multicolumn{1}{c|}{} & $\begin{array}{c}\mathrm{Ntc} \\
\left(\mathrm{kgep} / \mathrm{m}^{2} \cdot \text { year }\right)\end{array}$ \\
\hline Ntc $\max ($ Electric heater $\eta=1)$ & 4.76 \\
\hline Ntc $\min ($ Gas boiler, $\eta=1,09)$ & 3.07 \\
\hline Variation of primary energy needs & 1.69 \\
\hline
\end{tabular}

\subsection{Contribution of solar systems to DHW preparation}

In the last few decades, many ideas and technologies have been tested in order to increase the production of energy through renewable sources [3]. The energy efficiency by itself will not be enough to face the energy problems. It will be necessary to increase substantially the amount of renewable energy in the total energy production. This is in fact the principle behind the target "net zero energy buildings" established by the 2010 EPBD. Solar energy is considered as one of the most important forms of renewable energy [41]. The RCCTE requires the installation of solar collectors in all new buildings and existing buildings subject to major renovations.

The contribution of solar systems to DHW preparation (Esolar) was assessed through the analysis of different solar collectors. The analysed collectors were selected from the database of the official SOLTERM 5.0 software [42], being the ones with the best and the worst circulation systems and thermosiphon systems.

The results in Table 15 prove the high influence of the solar collectors both on the Nac index and on primary energy needs.

Table 15. Differences between solutions with higher and lower Esolar

\begin{tabular}{|l|c|c|c|c|c|}
\cline { 2 - 4 } \multicolumn{1}{c|}{} & Nic & $\mathrm{Nvc}$ & $\mathrm{Nac}$ & $\mathrm{Ntc}$ \\
\cline { 2 - 5 } \multicolumn{1}{c|}{} & \multicolumn{3}{c|}{$\left(\mathrm{kWh} / \mathrm{m}^{2} \cdot\right.$ year $)$} & $\left(\mathrm{kgep} / \mathrm{m}^{2} \cdot\right.$ year $)$ \\
\hline Esolar min =0 (Without solar collectors) & 86.39 & 3.75 & 27.02 & 4.86 \\
\hline $\begin{array}{l}\text { Esolar max = 2153kWh } \\
\text { (Collector “CPC ao Sol" - forced circulation) }\end{array}$ & 86.39 & 3.75 & 17.12 & 4.01 \\
\hline Variation of energy needs & 0.00 & 0.00 & 9.90 & 0.85 \\
\hline
\end{tabular}

\subsection{Heating system efficiency}

The heating system efficiency ( $\eta$ i) study was performed through the analysis of several kinds of equipment with different efficiencies and fed by different fuels.

The values recorded in Table 16 show that the heating system is one of the elements that most influences the primary energy needs and the final energy rating of the building.

Table 16 - Differences between solutions with high and low $\eta \mathrm{i}$

\begin{tabular}{|c|c|c|c|c|}
\hline & Nic & Nvc & $\mathrm{Nac}$ & \multirow{2}{*}{$\begin{array}{c}\text { Ntc } \\
\left(\mathrm{kgep} / \mathrm{m}^{2} \cdot \text { year }\right)\end{array}$} \\
\hline & \multicolumn{3}{|c|}{$\left(\mathrm{kWh} / \mathrm{m}^{2} \cdot\right.$ year $)$} & \\
\hline$\eta i \max =4.46$ (Heat pump) & 86.39 & 3.75 & 17.12 & 2.07 \\
\hline$\eta \mathrm{i} \min =1($ Electrical resistance $)$ & 86.39 & 3.75 & 17.12 & 4.01 \\
\hline Variation of energy needs & 0.00 & 0.00 & 0.00 & 1.94 \\
\hline
\end{tabular}




\subsection{Cooling system efficiency}

To evaluate the cooling system efficiency ( $\eta v)$, different air conditioning systems were considered.

The results presented in Table 17 provide confirmation that the cooling system efficiency has little influence on the Ntc index. This fact is due to the small value of the cooling needs and to the high efficiency of all studied systems. However, only the most common types of equipment in Portugal were studied.

Table 17. Differences between solutions with high and low $\eta v$

\begin{tabular}{|l|c|c|c|c|c|}
\cline { 2 - 5 } \multicolumn{1}{c|}{} & Nic & Nvc & Nac & Ntc \\
\cline { 2 - 5 } \multicolumn{1}{c|}{} & \multicolumn{3}{c|}{$\left(\mathrm{kWh} / \mathrm{m}^{2} \cdot\right.$ year $)$} & $\left(\mathrm{kgep} / \mathrm{m}^{2} \cdot\right.$ year $)$ \\
\hline$\eta$ Max (air conditioning systems with $\eta=5.15)$ & 86.32 & 3.76 & 17.12 & 4.01 \\
\hline Variation of enditioning systems with $\eta=3)$ & 86.32 & 3.76 & 17.12 & 4.00 \\
\hline
\end{tabular}

\section{Discussion}

The study allows for the comparison between the best and the worst solutions for each parameter and for each energy index. Those differences are presented in absolute and relative values in Figure 5 .

The relative values presented in Figure 5 correspond to the ratio between the best and the worst solution and the reference solution as presented in equation 1.

Relative difference $=\frac{\text { Best solution Value }- \text { Worst Solution Value }}{\text { Reference Solution Value }} \times 100$

(1)

\begin{tabular}{|c|c|c|c|c|c|c|c|c|}
\hline \multirow{3}{*}{ Puraneter } & \multicolumn{8}{|c|}{ Energy Indexes } \\
\hline & \multicolumn{2}{|l|}{ Nic } & \multicolumn{2}{|c|}{ Nve } & \multicolumn{2}{|l|}{ Nac } & \multicolumn{2}{|l|}{ Ntc } \\
\hline & $\mathrm{kWh} / \mathrm{m}^{2}$,ano & $\%$ & $\mathrm{kWh} / \mathrm{m}^{2}$-ano & $\%$ & $\mathrm{kWh} / \mathrm{m}^{2}$.ano & $\%$ & $\mathrm{kgep} / \mathrm{m}^{2}$.ano & $\%$ \\
\hline Heal Irausfer ceefficjent of esterior walls & 8,6 & 10 & 0,5 & 14 & 0,0 & 0 & 0,2 & 6 \\
\hline Fleat transfer coeffecient of interior walls & 0,0 & 0 & 0,0 & 0 & 0,0 & 0 & 0,0 & 0 \\
\hline Fleat transfer coeflicient of slabs & 15,9 & 18 & 0,0 & 0 & 0,0 & 0 & 0,5 & II \\
\hline Hleat transfer coefficient of fliemal lwiches & 0,7 & 1 & 0,0 & I & 0,0 & 0 & 0,0 & 0 \\
\hline Heat transfer coefficient of placing & 8,4 & 10 & 1,0 & 27 & 0,0 & 0 & 0,2 & 6 \\
\hline Number of indowr air chwyoses per hour & 12,0 & 14 & 2,8 & 73 & 0,0 & 0 & 0,3 & 8 \\
\hline Sumrmer Solar Factor (Glaking analysis) & 3,2 & 4 & 1,5 & 39 & 0,0 & 0 & $0_{2} 1$ & 3 \\
\hline Sunmer Selar Factor (External prefection analysis) & 0,0 & 0 & 4,2 & 113 & 0,0 & 0 & 0,0 & 1 \\
\hline Winter Solar Factor & 6,5 & 8 & 0,0 & 0 & 0,0 & 0 & 0,2 & 4 \\
\hline Shreling fictor (Florizonlal shadinge) & 3,6 & 4 & 2,3 & $\theta 0$ & 0,0 & 0 & 0,1 & 2 \\
\hline Shading factor (Vertical shading?) & 2,3 & 3 & 0,5 & 13 & 0,0 & 0 & 0,1 & 2 \\
\hline Absonglian coefficient (u) & 0,0 & 0 & 1,3 & 34 & 0,0 & 0 & 0,0 & 0 \\
\hline 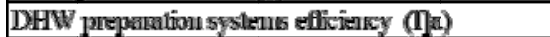 & 0,0 & 0 & 0,0 & 0 & 10,9 & 64 & 1,7 & 42 \\
\hline Ceniribution of solur systems to DIIW prepenation & 0,0 & 0 & 0,0 & 0 & $9 \overline{9}$ & 58 & 0,9 & 21 \\
\hline Heating system efficieney (Ti) & 0,0 & 0 & 0,0 & 0 & 0,0 & 0 & 1,9 & 48 \\
\hline Cooling system efficiency ( (I) & 0,0 & 0 & 0,0 & 0 & 0,0 & 0 & 0,0 & 0 \\
\hline
\end{tabular}

Figure 5. Differences between solutions with the best and worst performance regarding each studied parameter

Through the study it was possible to verify that the parameters which have a greater influence on heating energy needs were the heat transfer coefficient of slabs, external walls and glazing and the indoor air change rate. However, the window solar factor also had a relevant influence on these needs. 
The heat transfer coefficient of the slabs has, in this case study, a great influence on the heating energy needs. The relative difference between the best and worst solutions analysed for this parameter was $18 \%$. This is due to the large slab area that is part of the building envelope, which increases the losses through these elements.

Concerning the cooling needs, the most influent parameters were the windows' solar factor, the indoor air change rate and the shading factor (especially horizontal shading devices).

It was verified that the shading factor has significant influence on the heating and cooling needs. However, the shading devices decrease the cooling needs but increase the needs during the heating season. Thus, it is necessary to study carefully the solutions for these devices in order to find the best alternative for both seasons.

Only two of the studied parameters interfered with the DHW energy needs and both have a huge influence on them: the contribution of solar systems to DHW preparation (with a relative difference of $64 \%$ between the best and worst solution) and the DHW preparation system efficiency (with a relative difference of $58 \%$ ).

In reference to the primary energy needs, the most influential parameters were the heating system efficiency, the contribution of solar systems to DHW preparation and the efficiency of DHW preparation systems. The relative difference obtained for these parameters regarding the primary energy needs was $48 \%, 21 \%$ and $42 \%$ respectively, while the fourth parameter with the highest influence (heat transfer coefficient of slabs) had a relative difference of $11 \%$.

Although the heat transfer coefficient of slabs and external walls and the indoor air change rate have some influence on the primary energy needs, the parameters associated with the heating and cooling needs have less influence on the Ntc index than the parameters related to the DHW energy needs. Thus, in order to change the building energy rating, this last parameter and the system's efficiency are those which should be changed. However, parameters such as heat transfer coefficient, indoor air change rate, shading devices and solar factor should be carefully analysed because they are important for building comfort.

\section{Conclusions}

The methodology adopted in the study can be applied to other buildings located in other Portuguese geographic zones, while taking into account the future regulation that will arise from the transposition of the requirements of the new 2010 EPBD.

The study allows some conclusions to be drawn regarding the influence of RCCTE parameters on the final energy rating of a single-family detached house located in the North of Portugal.

It was observed that the parameters with the highest influence on the cooling and heating needs (heat transfer coefficient and solar factor) do not have a significant influence on the primary energy needs. On the other hand, the parameters with the highest influence on the Nac index are very influential on the primary energy needs. In fact, due mainly to political reasons, which translate into the regulation calculations, the parameters related to DHW preparation have a huge influence on the primary energy needs, and hence on the energy label, as opposed to the cooling and heating needs provoked by the envelope. For this reason, the importance of envelope-related parameters is low. However, some parameters do not exert a substantial influence on the buildings' energy needs but are very important for heating and cooling needs. Thus, it was important to study each parameter not only to achieve a good certification rating but also to improve the comfort of the buildings' occupants.

Through the analysis, it is possible to conclude that the RCCTE assigns great relevance to cooling, heating and DHW preparation systems, as well as solar systems to the detriment of some important parameters for building comfort (i.e. heat transfer coefficient and glazing). It was observed that, if these systems have a good efficiency, it would be easier to obtain a good certification rating, regardless of the solution adopted for the other parameters. This situation should be carefully reviewed because, although the systems are the most energy-consuming parts of the buildings, a 
piece of building thermal legislation should not overlook the comfort-related parameters nor the passive solutions for energy efficiency.

\section{References}

[1] Radhi, H., Evaluating the potential impact of global warming on the UAE residential buildings - A contribution to reduce the CO2 emissions. Building and Environment 44 (2009) 2451-2462.

[2] Deuble, M. P., Dear, R. J., Green occupants for green buildings: The missing link?. Building and Environment 56 (2012) 21 e 27.

[3] Piemont V., De Falco M., Tarquini P., Giaconia A., Life Cycle Assessment of a high temperature molten salt concentrated solar power plant. Solar Energy 85 (2011) 1101-1108.

[4] Kornelakis A., Multiobjective Particle Swarm Optimization for the optimal design of photovoltaic gridconnected systems. Solar Energy 84 (2010) 2022-2033.

[5] Climate change 2007. Synthesis Report, Intergovernmental Panel of Climate Change. Available from: http://www.ipcc.ch/.

[6] EEA, European Environment Energy. Energy and non-energy related greenhouse gas emissions (ENER 001) - Assessment published Aug 2011, available at http://www.eea.europa.eu assessed on 12/06/2012

[7] Biresselioglu M. E., Karaibrahimoglu Y. Z., The government orientation and use of renewable energy: Case of Europe. Renewable Energy 47 (2012) 29 e 37.

[8] Energy and environment report 2008, Report No 6/2008. European Environment Agency, Copenhagen 2008. ISBN 978-92-9167-980-5.

[9] Green Paper towards a European strategy for the security of energy supply; 2000. COM 769 final.

[10] Dixit, M.K., Fernández-Solís, J.L., Lavy, S., Culp, C.H., 2010. Identification of parameters for embodied energy measurement: a literature review. Energy and Buildings 42, 1238-1247.

[11] CIWMB, 2000. Designing with vision: a technical manual for materials choices in sustainable construction. California Integrated Waste Management Board.

[12] Directive 2010/31/EU of the European Parliament and of the council of 19 May 2010 on the energy performance of buildings (recast); Official Journal of the European Communities.

[13] Energy Efficiency Plan 2011. COM(2011) 109 final.

[14] Action plan for energy efficiency: realising the potential, 2006. COM 545 final.

[15] Urge-Vorsatz D, Harvey LDD, Mirasgedis S, Levine MD. Mitigating CO2 emissions from energy use in the world's buildings. Building Research and Information 2007b;35(4):379e98.

[16] DGEG, Direcção Geral de Energia e Geologia, 2011, Available from: http://www.dgge.pt/ (consulted in 2011/1/4).

[17] Parameshwaran R., Kalaiselvam S., Harikrishnan S., Elayaperumal A., Sustainable thermal energy storage technologies for buildings: A review. Renewable and Sustainable Energy Reviews 16 (2012) 2394- 2433.

[18] Mancisidor I., Uraga P., Macisidor I., Lopez P., European Union's renewable energy sources and energy efficiency policy review: The Spanish perspective. Renewable and Sustainable Energy Reviews 13 (2009) $100-114$.

[19] Directive 2006/32/EC of the European Parliament and of the council of 5 April 2006 on the energy enduse efficiency and energy services.

[20] Directive 2005/32/EC the European Parliament and of the council of 6 July 2005 establishing a framework for the setting of ecodesign requirements for energy-using products (EuP) on the promotion of the use of biofuels or other renewable fuels for transport.

[21] Directive 2004/8/EC of the European Parliament and of the council of 11 February 2004 on the promotion of cogeneration based on a useful heat demand in the internal energy market.

[22] Directive 2003/30/EC of the European Parliament and of the council of 8 May 2003 on the promotion of the use of biofuels or other renewable fuels for transport.

[23] Directive 2002/91/EC of the European Parliament and of the council of 16 December 2002 on the energy performance of buildings; Official Journal of the European Communities.

[24] Andaloro A. P. F., Salomone R., Loppolo G., Andaloro L., Energy certification of buildings: A comparative analysis of progress towards implementation in European countries. Energy Policy 38 (2010) $5840-5866$.

[25] Mlecnik, E., Visscher, H., Van Hal, A., 2010. Barriers and opportunities for labels for highly energyefficient houses. Energy Policy. 38, 4592-4603. 
[26] Ferreira J., Pinheiro M., In search of better energy performance in the Portuguese buildings — The case of the Portuguese regulation. Energy Policy 39 (2011) 7666-7683.

[27] Ferreira, J. V., Domingos, I., Assessment of Portuguese thermal building legislation in an energetic and environmental perspective. Energy and Buildings 43 (2011) 3729-3735.

[28] Decree-Law n $78 / 2006$ - Sistema Nacional de Certificação Energética e da Qualidade do Ar Interior nos Edifícios (SCE); Diário da República ${ }^{\circ} 67$ Série I-A de 4 de Abril de 2006.

[29] Decree-Law no 79/2006 - Regulamento dos Sistemas Energéticos e de Climatização de Edifícios; Diário da República n ${ }^{\circ} 67$ Série I-A de 4 de Abril de 2006.

[30] Decree-Law no 80/2006 - Regulamento das Características de Conforto Térmico de Edifícios; Diário da República $n^{\circ} 67$ Série I-A de 4 de Abril de 2006.

[31] Silva P., Silva S., Almeida M., Bragança L., Accuracy of the portuguese EPBD implemented thermal performance calculation procedures - RCCTE. Eleventh International IBPSA Conference. Glasgow, Scotland July 27-30, 2009.

[32] ADENE, Sistema de Certificacão Energética - Geral, 2009, Available at www.adene.pt, assessed in $12 / 06 / 2012$.

[33] Pilkington B., Grove S., Thermal conductivity probe length to radius ratio problem when measuring building insulation materials. Construction and Building Materials 35 (2012) 531-546.

[34] EN ISO 10211-1, Thermal bridges in building construction: heat flows and surface temperatures. Detailed Calculations (2007)

[35] Larbi A. B., Statistical modelling of heat transfer for thermal bridges of buildings. Energy and Buildings 37 (2005) 945-951.

[36] Tadeu A., Simões I., Simões N., Prata J., Simulation of dynamic linear thermal bridges using a boundary element method model in the frequency domain. Energy and Buildings 43 (2011) 3685-3695.

[37] Evola G., Margani G., Marletta L., Energy and cost evaluation of thermal bridge correction in

Mediterranean climate. Energy and Buildings 43 (2011) 2385-2393.

[38] Santos, Carlos A. Pina dos, Matias, Luís; Coeficientes de Transmissão Térmica de Elementos da Envolvente dos Edifícios; ICT Informação Técnica Edifícios - ITE50; Versão Actualizada de 2006; Laboratório Nacional de Engenharia Civil;

[39] Wullschleger L., Manz H., Wakili G. K., Finite element analysis of temperature-induced deflection of vacuum glazing. Construction and Building Materials 23 (2009) 1378-1388.

[40] Said M. N. A., Measurements of air change rates and air flow patterns in large single-cell buildings. Energy and Buildings 26 (1997) 175-182.

[41] Varun, Sharma N., Bhat I.K., Grover D., Optimization of a smooth flat plate solar air heater using stochastic iterative perturbation technique. Solar Energy 85 (2011) 2331-2337.

[42] SOLTERM version 5, Programme for Analysis of Photovoltaic and Solar Thermal Systems Performance. Copyright 1996, 2000, 2006, Instituto Nacional de Engenharia, Tecnologia e Inovação, I.P.

[43] Panão M., Camelo S., Gonçalves H., 2011. Assessment of the Portuguese building thermal code: Newly revised requirements for cooling energy needs used to prevent the overheating of buildings in the summer. Energy $36-3262$ e 3271

[44] Dascalaki E., Balaras C., Gaglia A., Droutsa K., Kontoyiannidis S., 2012. Energy performance of buildings - EPBD in Greece. Energy Policy 45 - 469-477.

[45] Tronchin L., Fabbri K., 2012. Energy performance certificate of building and confidence interval in assessment: An Italian case study. Energy Policy 48 -176-184.

[46]Ekins P., Lees E., 2008. The impact of EU policies on energy use in and the evolution of the UK built environment. Energy Policy 36 - 4580-4583. 